\title{
CHILDREN'S DAIRY PRODUCTS FOR ENTERAL NUTRITION
}

${ }^{1}$ Aнтипова T.A., доктор биологических наук

${ }^{1}$ Фелик $\boldsymbol{C}$.B., кандидат биологических наук

${ }^{1}$ Симоненко C.B., доктор технических наук

${ }^{2}$ Коробейникова T.B., кандидат технических наук

${ }^{1}$ Antipova T.A., doctor of biological sciences

${ }^{1}$ Felik $\boldsymbol{S}$. $\boldsymbol{V}$., candidate of biological sciences

${ }^{1}$ Simonenko $S$. $V$., doctor of technical sciences

${ }^{2}$ Korobeynikova T.V., candidate of technical sciences

${ }^{1}$ НИИ детского питания - филиал ФИЦ питания и биотехнологии, Истра

${ }^{2}$ ФИЦ питания и биотехнологии, Москва

\author{
${ }^{1}$ Research Institute of Baby Food - branch of FIC \\ of nutrition and biotechnology, Istra \\ ${ }^{2}$ FIC of nutrition and biotechnology, Moscow
}

В статье рассмотрены научные подходы к созданию детских молочных продуктов для энтерального питания. Дано определение энтерального питания в соответствии с требованиями Технического регламента. Приведена классификация продуктов для энтерального питания и изложены основные требования. Приведены результаты исследований по созданию белкового модуля для разработки состава детского молочного продукта для энтерального питания.

The article deals with scientific approaches to the creation of children's milk products for enteral nutrition. The definition of enteral nutrition is given in accordance with the requirements of the Technical Regulations. The classification of products for enteral nutrition is given and basic requirements are set out. The results of studies on the creation of a protein module for developing the composition of a baby dairy product for enteral nutrition are presented. 
Ключевые слова: пищевой статус, энтеральное питание, белковый модуль, антиоксидантная активность.

Keywords: food status, enteral nutrition, protein module, antioxidant activity.

В последние годы особое внимание уделяется вопросам рационального питания детей, находящихся на стационарном лечении. Статистические данные свидетельствуют, что 30-40\% пациентов педиатрических стационаров имеют нарушения пищевого статуса. Нарушение пищевого статуса снижает иммунорезистентность, увеличивает риск инфекций, ухудшает процессы регенерации, вызывает гастроинтестинальную дисфункцию, увеличивает затраты на лечение. Поэтому в настоящее время стандарт лечебных мероприятий включает «нутритивную поддержку», задачей которой является обеспечение больных полноценным питанием [1].

Нутритивная поддержка имеет важное значение при проведении лечебных мероприятий у пациентов детского возраста. В силу имеющихся у ребенка метаболических особенностей, связанных с физиологической и функциональной незрелостью детского организма, в частности, со сниженной активностью ферментативных процессов, нередко наблюдается питательная недостаточность (ПН), которая ярко проявляется при длительном нахождении в клинике. При обнаружении у ребенка ПН лечащим врачом решается вопрос обеспечения пациента полноценным питанием, необходимым для жизни и развития, существенное место при этом занимает энтеральное питание (ЭП) [2].

Согласно ТР ТС 027/2012, пищевая продукция энтерального питания жидкая или сухая (восстановленная до готовой к употреблению) пищевая продукция диетического лечебного или диетического профилактического питания, предназначенная для перорального употребления непосредственно или введения через зонд при невозможности обеспечения организма пищевыми веществами и энергией обычным способом [3].

При назначении энтерального питания, а также при выборе состава питательных смесей и определении дозировки необходим контроль за степенью нарушений пищевого статуса. На первом этапе с помощью сбора анамнеза и клинического обследования больных выявляют группы риска по недостаточности питания. У больных, отнесенных к группе риска, проводится более де- 
тальная оценка состояния питания и при необходимости назначается соответствующее лечение [4].

Смеси для энтерального питания детей имеют ряд особенностей и должны отвечать следующим требованиям:

- легко перевариваться и усваиваться организмом ребенка;

- обеспечивать оптимальное соотношение азот: небелковые калории - 1:120-150;

- иметь определенные соотношения между основными макронутриентами, быть сбалансированными по составу;

- $\quad$ содержать все необходимые пищевые вещества (белки, жиры, углеводы, минеральные соли, микроэлементы, витамины) в количествах, отвечающих всем потребностям организма, в том числе и энергетическим;

- обладать низкой осмолярностью для исключения таких осложнений, как тошнота, рвота, диарея, судороги;

- не вызывать симптомов метеоризма, стимуляции моторноэвакуаторной активности;

- $\quad$ не содержать в своем составе лактозы и глютена $[5,6,7]$.

Выбор смесей для адекватного энтерального питания должен быть основан на данных клинического, инструментального и лабораторного обследования больных, связан с характером и тяжестью течения заболевания и степенью сохранности функций желудочно-кишечного тракта (ЖКТ). Для детского питания обычно используют: стандартные, полуэлементные и модульные смеси.

Стандартные смеси содержат все необходимые макро- и микронутриенты в соответствии с суточными потребностями организма. Белки содержатся в цельном, негидролизованном виде (молочные, соевые). Жиры представлены растительными маслами (подсолнечное, соевое, кукурузное и др.), углеводы - в виде мальтодекстринов (гидролизаты крахмала). Стандартные смеси используются в большинстве клинических ситуаций, когда имеются показания для энтерального питания, за исключением выраженных нарушений пищеварения и всасывания нутриентов, а также органной патологии (печеночной, почечной и др.) [8].

Полуэлементные смеси представляют собой также полностью сбалансированные нутриенты, в которых белки представлены в виде пептидов и аминокислот (белковых гидролизатов). Они назначаются при выраженных расстройствах пищеварительной и всасывательной функций (мальабсорбции, диарее), в том числе в ранний послеоперационный период. 
Модульные смеси содержат только один из нутриентов (белок, жир) или отдельные аминокислоты, регуляторы метаболизма. Они используются для дополнения рациона искусственного или обычного лечебного питания.

Ограниченный ассортимент продуктов энтерального питания для этого контингента больных, особенно детей первого года жизни, не позволяет осуществлять персонифицированный подход к назначению диетологической коррекции и затрудняет решение проблемы. Кроме того, на рынке клинического питания в этом сегменте продукция отечественного производства не представлена, что служит основанием для проведения настоящих исследований.

В связи с этим Научно-исследовательский институт детского питанияфилиал Федерального государственного бюджетного учреждения науки Федерального исследовательского центра питания, биотехнологии и безопасности пищи проводит научные исследования в области создания современных технологий продуктов для энтерального питания.

Целью исследования являлось обоснование технологических требований к энтеральным продуктам для питания детей раннего возраста и проектирование белкового модуля энтерального продукта с использованием в его составе низкомолекулярных пептидов молока.

Данная научно-исследовательская работа проведена за счет средств субсидии на выполнение государственного задания в рамках Программы Фундаментальных научных исследований государственных академий наук на 2013-2020 гг. по направлению № 0529-2016-0039.

Для обоснования технологических требований авторами проведен литературный обзор по направлению исследований, включающий обобщение результатов отечественных и зарубежных ученых по энтеральному питанию.

В современной литературе отмечается, что энтеральная смесь должна представлять собой раствор, в составе которого содержатся: иммуномодулятор, витамины и так называемые энергетические субстраты (мальтодекстрины).

Использование такого комплекса в ранний период после травмы или операции способствует нормализации деятельности желудочно-кишечного тракта, что позволяет избежать тяжёлой неспецифической стресс-реакции организма. Для облегчения процесса всасывания и усвоения, а также для предотвращения возможной осмотической диареи осмолярность энтеральной смеси должна составлять 285-295 мОсмоль/л. Активная кислотность смеси должна находиться в пределах 6,0-7,0 ед. $\mathrm{pH}$ для создания «комфортных» ус- 
ловий в желудочно-кишечном тракте. Динамическая вязкость смеси не должна превышать 15 мПа·с, чтобы не возникало проблем при прохождении смеси через зонд. Величина седиментационной устойчивости энтеральной смеси - 100 \%. В 500 г восстановленной смеси должна содержаться суточная норма иммуномодулятора.

В основу выбора источника биологически активных пептидов в продуктах положен сравнительный анализ интегральной антиоксидантной активности возможных белковых препаратов. В качестве объектов исследования выбраны: коровье молозиво и концентрат сывороточного белка (КСБ). Установлено, что коровье молозиво имело в 3 раза большую активность, чем препарат КСБ.

Для получения биологически активных пептидов проводили биоконверсию коровьего молозива ферментными препаратами животного, бактериального и грибкового происхождения.

Изучение относительного молекулярно-массового распределения белков в гидролизатах после 1 часа гидролиза Панкреатином при фермент/субстратном соотношении 1:20 показало снижение фракции белков с молекулярной массой $>276$ кДа в 6 раз, при этом фракция с молекулярной массой 276-72,9 кДа (которая включала иммуноглобулины) количественно не изменилась. Максимальное количество (до 27\%) низкомолекулярных пептидов с молекулярной массой менее 1,1 кДа получено при гидролизе в течение 5 часов. Таким образом, фракция низкомолекулярных пептидов меньше 6,9 кДа составила 50\% при гидролизе Панкреатином в течение 5 часов; степень гидролиза не превышала $6,5 \%$.

Отмечено, что антиоксидантные свойства молозива, подвергнутого гидролизу Панкреатином в течение 5 часов, на $30 \%$ превышали нативный образец.

Осмоляльность гидролизатов молозива, полученного с помощью Панкреатина, количественно возрастала с увеличением продолжительности гидролиза и составила $750 \pm 2$ мОсм/кг, что в 2 раза превышает показатель нативного образца молозива.

Оценка относительного молекулярно-массового распределения белков в гидролизатах с использованием бактериального препарата Protamex при фермент/субстратном соотношении 1:25 показало незначительное снижение фракции с молекулярной массой 276-72,9 кДа при максимальном времени гидролиза. Фракция низкомолекулярных пептидов меньше 6,9 кДа не превысила $35 \%$, степень гидролиза составила $2 \%$. 
Введение бактериальной протеазы увеличило интегральную антиоксидантную активность гидролизатов на 45\% по сравнению с негидролизованным образцом коровьего молозива.

Осмоляльность гидролизатов с Protamex не превышала значений 760 $\mathrm{MOcм} / \mathrm{кг.}$

Гидролиз с использованием грибковой протеазы Флавоэнзим показал увеличение фракции пептидов менее 6,9\% до 40\% в течение 24 часов. Содержание пептидов фракции 276-72,9 кДа в течение всего времени проведения гидролиза составило 20\%. Фракция низкомолекулярных пептидов меньше 6,9 кДа составила 40\%, степень гидролиза 2,5\%.

Антиоксидантная активность гидролизата при продолжительности гидролиза 24 часа была ниже на 10\%, чем при использовании фермента Protamex. Показатель осмоляльности превышал показатель нативного молозива в 2 раза.

Изучен аминокислотный состав ферментативных гидролизатов коровьего молозива, полученных с помощью ферментативного препарата Protamex. С помощью программы Statistica 6.0 спроектирован белковый модуль с введением в состав гидролизатов коровьего молозива, в качестве задаваемых параметров выбраны: аминокислотный состав, который должен быть максимально приближен к аминокислотному составу эталонного белка грудного молока, и показатель осмоляльности, оптимум которого должен составлять 290-320 мОсм/кг.

В качестве основы при расчете состава продукта использовали концентрат сывороточных белков с варьированием различного количества полученных гидролизатов коровьего молозива. Установлено, что введение в состав продукта модуля, содержащего 80-85\% КСБ и 15-20\% гидролизата, позволяет повысить биологическую ценность продукта. Данный модуль не несет значительной осмотической нагрузки. Содержание незаменимых аминокислот при данном соотношении более чем на $85 \%$ соответствует аминокислотному составу эталонного белка женского молока.

\section{Библиографический список}

1. Лазарев, В.В. Современные подходы к парентеральному питанию у детей / В.В. Лазарев, Л.Е. Цыпин, А.А. Корсунский // Детская больница. 2007. - № 2. - С. 36-37.

2. Берестенникова, Л.Н. Особенности применения и экономическая эффективность полуэлементных смесей для энтерального питания детей в кри- 
тических состояниях / Л.Н. Берестенникова // Педиатрическая фармакология. 2015; 12 (4): 392-397.

3. Технический регламент таможенного союза ТР ТС 027/2012 «О безопасности отдельных видов специализированной пищевой продукции, в том числе диетического, лечебного и диетического профилактического питания〉.

4. Инструкция по организации энтерального питания в лечебнопрофилактических учреждениях (приложение 5), утвержденная приказом Минздрава РФ от 5 августа 2003 г., № 330.

5. Приказ Минздрава РФ от 5 августа 2003 г. N 330 «О мерах по совершенствованию лечебного питания в лечебно-профилактических учреждениях Российской Федерации».

6. Методические рекомендации по применению смесей «НУТРИЭН» для диетического лечебного питания (утв. R.S.P.E.N. от 4 марта 2009 г.).

7. Ерпулева, Ю.В. Опыт применения смесей для энтерального питания у детей в условиях интенсивной терапии / Ю.В. Ерпулева // Вопросы современной педиатрии. - 2005; 5 (4): 59-61.

8. Барановский, А.Ю. Диетология / А.Ю. Барановский. - СПб., 2012. $1024 \mathrm{c}$. 